\title{
Public vs. Private: The Evaluation of Different Space Types in Terms of Publicness Dimension
}

\author{
Elif Kutay Karaçor ${ }^{1}$
}

\begin{abstract}
Most of researchers from various disciplines assert conflicting definitions about public spaces. In this context, when some researchers express the decline of public spaces, others claim that the contemporary public spaces are quite inclusiveness and revival. However, the common features expected from all public spaces are: provide opportunities for social life, include various activities, convenient to use by access and linkage, and has unique identity with image. It is accepted that all these features contribute to publicness of public spaces which increase the sustainable development of the city. Aim of this study is to determine publicness of different urban spaces types and making comparison among them. Thereby, publicness dimension of urban spaces which have public or private ownership will be revealed and a new contribution to public space arguments will be made. Duzce city center was chosen as a research area since its rapidly development and transformation process after the 1999 earthquakes. As a research method, different public space types were illustrated and these illustrations were interpreted by site observations. Consequently, publicness and public use were found as not directly related with their public or private ownership, so political and commercial forces behind urban spaces that influenced on public life were debated.
\end{abstract}

Key words: public space, publicness, privatization

\section{Introduction}

Public spaces were designed to support human interaction and political debate since from the ancient times, and these spaces provide opportunities to interact with strangers and observe the others. Public space definitions have been diversified since their differentiation according to their ownership, control, access and use especially last three decades. Some authors defined them as not controlled by private individuals or sectors, and open to all public by focusing on the control mechanism, and other researchers focused on their access and use features rather than ownership and defined as publicly accessible places where people go for their activities. So privately owned spaces that are accessible ones were qualified as public spaces and publicly owned spaces were not qualified as public spaces if they are not accessible to the public (Mehta, 2014). Shrinkage of the governments for neoliberal market led to withdrawing of the public realm. Eventually, goods and services decreased which are provided by the governments, and nonprofit sectors have increased. Banerjee (2001) criticized this process since most of the public goods and services including public spaces were commodified.

Since the 19th century, urban reformers, city planners, and municipal officials have claimed that public spaces are ended in terms of socially and politically (Nemeth and 
Schmidt, 2011). Sennett (1996) was the first known researchers claimed that the 'end of public space' and assert the declining public space and public realm because of social, political and economic factors leading to a privatization of people's lives. Following researchers assert that fear of crime and safety needs that are stimulated in the societies lead to emergence of privately owned, maintained and controlled spaces, and they criticized commodification and homogenization of spaces include shopping malls, festival marketplaces and casinos, surveillance cameras, militaristic policing, joint publicprivate funding arrangements, covered walkways, and even quasi-gated communities (Sorkin, 1992; Mitchell, 1995; Davis, 1992; Loukaitou-Sideris and Banerjee, 1998; Zukin, 1998; Boyer, 1996; Iveson, 1998).

On the contrary, other researchers believed that the decline in the public realm is a false aspect since public spaces have never been diverse, open to all public, or democratic (Loukaitou-Sideris and Banerjee, 1998; Carr et al., 1992). Besides, new forms of public life are believed as required new spaces, and creating new spaces are seen as a component of contemporary urban design (Carmona et al., 2003; Varna and Tiesdell, 2010).

However, the common features expected from all public spaces are: provide opportunities for social life, include various activities, convenient to use by access and linkage, and has a unique identity with an image. It is accepted that all these features contribute to publicness of public spaces which increase the sustainable development of the city. The aim of this study is to determine publicness of different urban spaces types and make a comparison among them. Therefore, the relationship between ownership and publicness of different type public spaces will be revealed for sustainable social life.

\section{Publicness of Public Spaces}

As similar to 'public space' term, there are some difficulties on the definition of 'publicness' term. Besides, it is believed that desires and outcomes of publicness are quite different in public spaces, and also since neo-liberal regeneration redefine spaces as private, attending to the public becomes ever more important (Varna and Tiesdell, 2010). The biggest argument in publicness issue is exclusion, and being 'visible and accessible' is considered as the core of publicness (Madden, 2010). According to Brighenti (2010), public means that open and visible to everyone, as opposed to private which is restricted and protected. Most of the researchers have a consensus about public spaces have to be accessible for everyone without considering about gender, religion, income level, and ethnicity, and visible without any restriction. The problem is contemporary public spaces such as shopping malls, gated communities, private city clubs, etc., are restricted in terms of accessibility and visibility. This control mechanism is provided by neoliberal policies that offer better public spaces only for specific and exclusive groups. Together with these features, crowded traffic, business activity, anti-social behavior and crime, poor design, conflicting roles and privatization of the public realm are considered as responsible for decrease of publicness (Williams and Green, 2001). Eventually, four main features that show publicness come forward; social life and socialization, activities, access and linkage, and identity and image. 


\subsection{Social Life and Socialization}

Public spaces should play an important role in the outdoor activities of urban residents and contribute to strengthening social interactions between citizens (Oliveira and Andrade, 2007). People can see their friends and meet their neighborhoods and interact with strangers (PPS, 2016). However, today's people especially privilege ones (high income, ethnic or religion majorities) are tended to be contacted only with people from similar groups. Unfortunately, neoliberal policies stimulate this situation for taking control and manage to spaces and privately owned public spaces are created. These spaces are criticized by most of the researchers because of restricting social interaction, constraining individual liberties and excluding certain undesirable populations (Nemeth, 2009).

\subsection{Activities}

Activities are believed as the basis for a place. Activities give a reason to people for come to a place - and return. Empty places give an impression about something is wrong (PPS, 2016). Montgomery (1998), claimed that activity has two related concepts: vitality and diversity. Vitality refers to the numbers of people in and around the public space at different times of the day and night, the number of cultural events and celebrations over the year, the presence of an active street life, and feeling alive or lively. Montgomery (1998) emphasized the long term urban vitality that can be achieved by the only complex diversity of primary land uses and mostly economic activity including such things as tea houses and cafes, groceries, cake shops, cinemas and galleries, pubs and clubs.

The 'diversity' term ranges across a far wider set of indices such as locally owned or independent businesses and shops, existence of evening and night-time activity, the availability of cultural and meeting places offering service of different kinds at varying prices and degrees of quality, the presence of an active street life and building frontages etc., (Montgomery, 1998).

\subsection{Access and Linkage}

Accessibility of any spaces is about its connection to surroundings both visual and physical and it refers to the ease with which a place or facility can be reached by people. It is expected from a successful public space being visible and easy to get through. Accessible spaces are connected with public transit as well (PPS, 2016; Lotfi and Koohsari, 2009b). According to Madanipour (2010), places cannot become public without being accessible. If public spaces enclosed, their accessibility could be undermined. It is believed that public spaces in which have easy access can affect its vicinity property values positively and draw local trade development (Nemeth and Schmidt, 2011).

\subsection{Identity and Image}

Whilst identity is related to the characteristics of a place defined as the objective thing, the image is a combination of this identity with how a place is perceived by its users. Public spaces that are designed with the history and culture of the city or neighborhood in mind create a connection among users of these spaces (Dougherty, 
2006). The image of a place is set of feelings and impressions about that place for people. These feelings come from a filtering of information collected about the place. This filtering is partly based on individuals' values, beliefs, experience and ideas (Montgomery, 1998). The identity of a place connects it to its users and to the city.

\section{Duzce City Center as a Case Study}

Duzce city, our study area, is located between two metropolitan cities - Ankara and Istanbul - and its population increases due to migration from other cities. We selected this city as our study area because of its privatization process following the 1999 earthquakes. While it was known as a small district before the 1999 earthquakes, it received a province status after those disastrous earthquakes. Especially after the establishment of Duzce University and encouragement of new economic investments, a high number of people from other cities moved to Duzce and spatial transformations were accelerated in the city.

After the becoming province, governmental incentives were given to industrial areas and several economic sectors were developed accordingly. In addition to the establishment of Duzce University, Duzce city immigrated from other cities and rural areas. New residential areas were built around of outskirts of the city, and new urban services, shopping malls, and recreational facilities emerged in the city center. Also, some of publicly owned spaces were privatized and their attractiveness and design features have changed, as well.

\section{Method}

Detailed site observation method was applied in this study. Twenty urban space types (Table 1) from clearly public to clearly private space that are classified by Carmona (2010b) have been used for the illustration which based on site observation of the city. By way of illustration, and based on detailed on-site observation of Duzce city center, distribution of space types varies from place to place was demonstrated. Urban spaces from publicly owned to privately owned in Duzce City have been evaluated by four main features of publicness that are; social life and socialization, activities, access and linkage, and identity and image.

Table 1. Urban space types (Carmona, 2010b).

\begin{tabular}{|l|l|l|}
\hline Space type & Characteristics & Examples \\
\hline $\begin{array}{l}\text { 1. Natural/semi- } \\
\text { natural } \\
\text { urban space }\end{array}$ & $\begin{array}{l}\text { Natural and semi-natural features } \\
\text { within urban areas }\end{array}$ & $\begin{array}{l}\text { Rivers, natural features, seafronts, } \\
\text { canals }\end{array}$ \\
\hline 2. Civic space & $\begin{array}{l}\text { The traditional forms of urban } \\
\text { space, } \\
\text { open and available to all }\end{array}$ & Streets, squares, promenades \\
\hline $\begin{array}{l}\text { 3. Public open } \\
\text { space }\end{array}$ & $\begin{array}{l}\text { Managed open space, typically } \\
\text { green and available and open to all, } \\
\text { even if temporally controlled }\end{array}$ & $\begin{array}{l}\text { Parks, gardens, commons, urban } \\
\text { forests, cemeteries }\end{array}$ \\
\hline
\end{tabular}




\begin{tabular}{|c|c|c|}
\hline & 'Negative' spaces & \\
\hline 4. Movement space & $\begin{array}{l}\text { Space dominated by largely } \\
\text { motorized transportation }\end{array}$ & $\begin{array}{l}\text { Main roads, motorways, railways, } \\
\text { underpasses }\end{array}$ \\
\hline 5. Service space & $\begin{array}{l}\text { Space dominated by modern } \\
\text { servicing requirements needs }\end{array}$ & Car parks, service yards \\
\hline 6. Left over space & Space left over after development & $\begin{array}{l}\text { 'SLOAP' (space left over after } \\
\text { planning), Modernist open space }\end{array}$ \\
\hline \multirow[t]{2}{*}{ 7. Undefined space } & $\begin{array}{l}\text { Undeveloped space, either } \\
\text { abandoned or awaiting } \\
\text { redevelopment }\end{array}$ & $\begin{array}{l}\text { Redevelopment space, abandoned } \\
\text { space, transient space }\end{array}$ \\
\hline & Ambiguous spaces & \\
\hline $\begin{array}{l}\text { 8. Interchange } \\
\text { space }\end{array}$ & $\begin{array}{l}\text { Transport stops and interchanges, } \\
\text { whether internal or external }\end{array}$ & $\begin{array}{l}\text { Metros, bus interchanges, railway } \\
\text { stations, bus/tram stops }\end{array}$ \\
\hline $\begin{array}{l}\text { 9. Public 'private' } \\
\text { space }\end{array}$ & $\begin{array}{l}\text { Seemingly public external space, in } \\
\text { fact privately owned }\end{array}$ & $\begin{array}{l}\text { Privately owned 'civic' space, } \\
\text { business parks, } \\
\text { church grounds }\end{array}$ \\
\hline $\begin{array}{l}\text { 10. Conspicuous } \\
\text { spaces }\end{array}$ & $\begin{array}{l}\text { Public spaces designed to make } \\
\text { strangers feel conspicuous and, } \\
\text { potentially unwelcome }\end{array}$ & Cul-de-sacs, dummy gated enclaves \\
\hline $\begin{array}{l}\text { 11. Internalized } \\
\text { 'public' } \\
\text { space }\end{array}$ & $\begin{array}{l}\text { Formally public and external uses, } \\
\text { internalized and, often, privatized }\end{array}$ & $\begin{array}{l}\text { Shopping/leisure malls, } \\
\text { introspective mega structures }\end{array}$ \\
\hline 12. Retail space & $\begin{array}{l}\text { Privately owned but publicly } \\
\text { accessible } \\
\text { exchange spaces }\end{array}$ & $\begin{array}{l}\text { Shops, covered markets, petrol } \\
\text { stations }\end{array}$ \\
\hline $\begin{array}{l}\text { 13. Third place } \\
\text { spaces }\end{array}$ & $\begin{array}{l}\text { Semi-public meeting and social } \\
\text { places, public and private }\end{array}$ & $\begin{array}{l}\text { Cafes, restaurants, libraries, town } \\
\text { halls, religious } \\
\text { buildings }\end{array}$ \\
\hline $\begin{array}{l}\text { 14. Private 'public' } \\
\text { space }\end{array}$ & $\begin{array}{l}\text { Publicly owned, but functionally } \\
\text { and user determined spaces }\end{array}$ & $\begin{array}{l}\text { Institutional grounds, housing } \\
\text { estates, university } \\
\text { campuses }\end{array}$ \\
\hline $\begin{array}{l}\text { 15. Visible private } \\
\text { space }\end{array}$ & $\begin{array}{l}\text { Physically private, but visually } \\
\text { public space }\end{array}$ & $\begin{array}{l}\text { Front gardens, allotments, gated } \\
\text { squares }\end{array}$ \\
\hline 16. Interface spaces & $\begin{array}{l}\text { Physically demarked but publicly } \\
\text { accessible interfaces between public } \\
\text { and private space }\end{array}$ & Street cafes, private pavement space \\
\hline \multirow[t]{2}{*}{$\begin{array}{l}\text { 17. User selecting } \\
\text { spaces }\end{array}$} & $\begin{array}{l}\text { Spaces for selected groups, } \\
\text { determined (and sometimes } \\
\text { controlled) by age or activity }\end{array}$ & $\begin{array}{l}\text { Skateparks, playgrounds, sports } \\
\text { fields/grounds/ } \\
\text { courses }\end{array}$ \\
\hline & Private spaces & \\
\hline $\begin{array}{l}\text { 18. Private open } \\
\text { space }\end{array}$ & Physically private open space & $\begin{array}{l}\text { Urban agricultural remnants, private } \\
\text { woodlands, }\end{array}$ \\
\hline $\begin{array}{l}\text { 19. External private } \\
\text { space }\end{array}$ & $\begin{array}{l}\text { Physically private spaces, grounds } \\
\text { and } \\
\text { gardens }\end{array}$ & $\begin{array}{l}\text { Gated streets/enclaves, private } \\
\text { gardens, private } \\
\text { sports clubs, parking courts }\end{array}$ \\
\hline $\begin{array}{l}\text { 20. Internal private } \\
\text { space }\end{array}$ & Private or business space & Offices, houses, etc. \\
\hline
\end{tabular}




\section{Results}

A patchwork of different public space types put forward that natural / seminatural urban spaces which are defined as positive space and seen as a high degree of publicness are located in Duzce city center, as well. Asar riverside as one of positive public space flowing through city center is highly accessible in terms of physically and visually. However, it is used as transit space and city inhabitants do not spend their time on the riverside. This situation could arise from both insufficient activities and failure to provide for charming. Insufficient activities may also lead to decline in social relations.

Public open spaces that considered as having a high degree of publicness are located in the city center as another positive space. Inonu Park and Avni Akyol Park that the oldest public open spaces in the city are quite important for both developing of urban memory and bringing together different social and ethnic groups in the city such as Turkish, Circassian, Georgian, Abkhazian, etc. However, privately owned restaurants, cafes and amusement park decrease the accessibility of public open spaces for different income groups in the city. Also, perception as less secure after the daylight hours has restricted visiting the park by women and children.

Urban spaces which are classified under the negative spaces are located in Duzce city center, too. Abandoned spaces which are called as undefined spaces have not been improved since from the 1999 earthquake, and they remained as useless fields in the city. These spaces do not have any opportunities for socialization and activities. And besides, they contribute to the urban identity negatively because of representing the signs of the earthquake.

Shopping mall as one of the ambiguous urban spaces is located in the city center, and it was opened in 2012. Until that time, inhabitants of the city satisfied their shopping needs in retail spaces which are located in the streets or shopping malls in the nearby cities. These spaces are criticized in the literature because of privately owned and consuming oriented, even though they are used by mostly public purpose. Especially, access by marginal and low income groups are restricted by safety regulations and experiencing the city with all actors becomes difficult. However, being of consuming-oriented and privately owned do not reduce its attractiveness, unlike it has become a quite attractive space where people can meet, socialize and participate in several activities. Although it does not have any special character in terms of architecture, it is quite high in imageability because of location in the city. Military area and school gardens are another ambiguous spaces and they are classified as private 'public' spaces since publicly owned, but functionally and user determined spaces. Retail spaces and third places that other ambiguous spaces become more attractive with pedestrian spaces which provide access, and they largely attract people. The attractiveness of shopping and consumption spaces is increased by the desire of benefiting from products and services, and meeting other people. Wi-Fi services in third places and retail spaces along the street especially in appropriate weather conditions increase the usage of spaces (Figure 1).

Even if public access is largely restricted in several private spaces, gated enclaves which are called as external public spaces create socialization opportunities for their inhabitants. Also, they are limited in terms of publicness since only their inhabitants could communicate with each other and could participate in limited activity. 

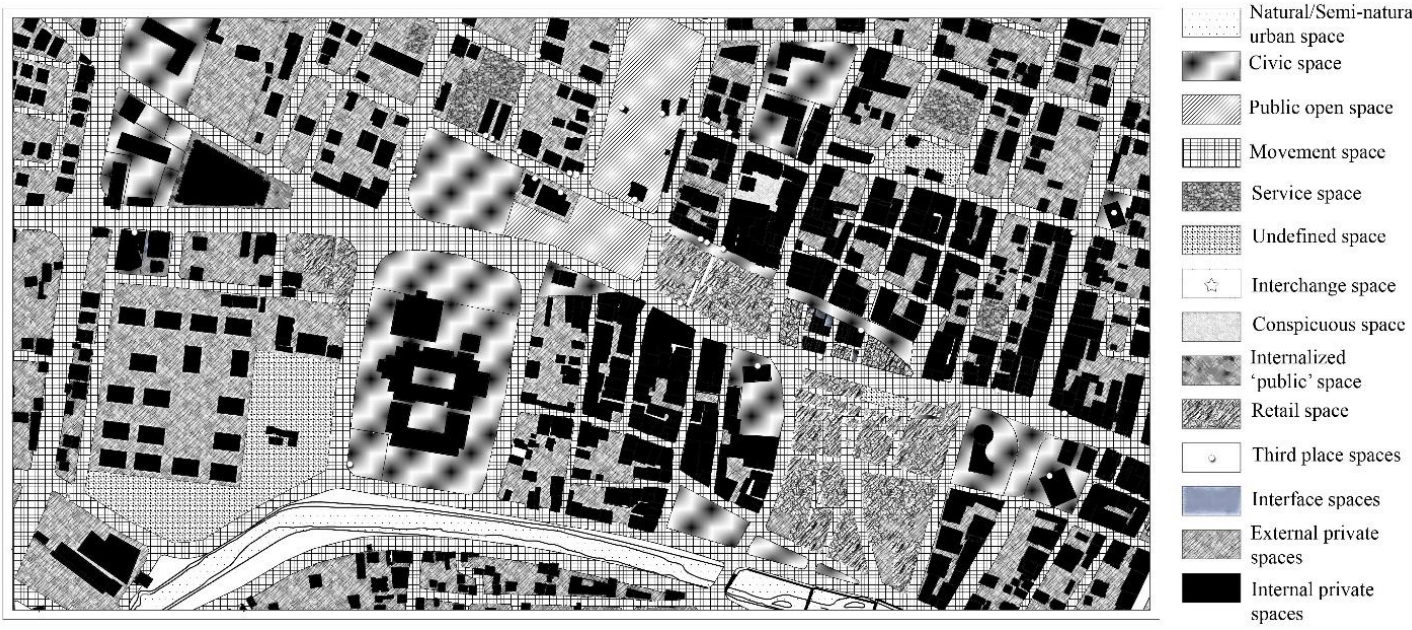

Figure 1. Space types in Duzce city center.

\section{Conclusion}

As indicated in Duzce city center private or public ownership have influenced on publicness of urban spaces. However, only ownership of spaces is not a key factor to their use or preference. While publicly owned spaces were not preferred by city inhabitants, but privately owned spaces were visited and used exceedingly in several times. Under-management policies, unsatisfactory control and insufficient safety perception of publicly owned spaces resulting from both privatization process and its spatial products could affect space preference. Besides, the existence and quality of the facility and equipment are also increasing the use and publicness of urban spaces. According to Brighenti (2010), Jane Jacobs insisted that the built in equipment of urban open spaces is necessary to sustain and enhance their publicness. However, attractive public spaces that contribute to meeting of all social groups should be located in the city centers. Social experience, tolerance, and familiarity could be provided only in this way and people can understand and sympathize with each other. This situation could be provided by social sensitivity only in publicly owned spaces. Increasing of publicness by the contribution of attractiveness is very important in traditional forms of urban spaces that called positive spaces such as squares and parks in terms of ecological and social sustainability.

According to Banerjee (2001), privatization, globalization, and the communications revolution will continue to shape the future demand and supply of public space. Therefore, urban planners and designers must anticipate the effects of these trends, but also focus on the concept of public life, which includes both private and public realms.

\section{References}

Banerjee, T. (2001). The future of public space: beyond invented streets and reinvented places. Journal of the American Planning Association, 67(1), 9-24.

Boyer, M. C. (1996). The city of collective memory. Journal of Clinical Laser Medicine and Surgery, 14(4), 404. 
Brighenti, A. (2010). The publicness of public space: On the public domain. Quaderni del Dipartimento di Sociologia e Ricerca Sociale; 49. Università di Trento. ISBN ISSN: 1828 - 955 X

Carmona, M., Heath, T., Oc, T. \& Tiesdell, S. (2003). Public Places Urban Spaces: The Dimensions of Urban Design (London: Architectural Press).

Carmona, M. (2010b). Contemporary public space, part two: classification. Journal of Urban Design, 15(2), 157-173.

Carr, S., Francis, M., Rivlin, L. G., and Stone, A. M. (1992). Public Space, London, Cambridge University Press.

Davis, M. (1992). Fortress Los Angeles: the militarization of urban space. Variations on a theme park, 154180.

Dougherty, D. (2006). Embodying the city: Identity and use in urban public space. Virginia Polytechnic Institute and State University in partial fulfillment of the requirements for the degree of Master of Landscape Architecture.

Iveson, K. (1998). Putting the public back into public space. Urban Policy and Research, 16(1), 21-33.

Lotfi, S., \& Koohsari, M. J. (2009b). Measuring objective accessibility to neighborhood facilities in the city (A case study: Zone 6 in Tehran, Iran). Cities,26(3), 133-140.

Loukaitou-Sideris, A., \& Banerjee, T. (1998). Urban design downtown: Poetics and politics of form. Univ of California Press.

Madanipour, A. (2010). Whose public space. Whose Public Space?: International Case Studies in Urban Design and Development, 237-242.

Madden, D. J. (2010). Revisiting the end of public space: assembling the public in an urban park. City \& Community, 9(2), 187-207.

Mehta, V. (2014). Evaluating public space. Journal of Urban Design, 19(1), 53-88.

Mitchell, D. (1995). The end of public space? People's Park, definitions of the public, and democracy. Annals of the Association of American Geographers, 85(1), 108-133.

Montgomery, J. (1998). Making a city: Urbanity, vitality and urban design. Journal of Urban Design, 3(1), 93116.

Nemeth, J. (2009). Defining a public: The management of privately owned public space. Urban Studies, 46(11), 2463-2490.

Nemeth, J., \& Schmidt, S. (2011). The privatization of public space: modeling and measuring publicness. Environment and Planning B: Planning and Design, 38(1), 5-23.

Oliveira, S., \& Andrade, H. (2007). An initial assessment of the bioclimatic comfort in an outdoor public space in Lisbon. International Journal of Biometeorology, 52(1), 69-84.

PPS, 2016. What Makes a Successful Place? http://www.pps.org/reference/grplacefeat/

Sennett, R. (1996). Kamusal Insanin Çokusu (In Turkish). Published by Ayrinti Yayinlari. Istanbul.

Sorkin, M. (1992). Variations on a theme park: The new American city and the end of public space. Macmillan.

Varna, G., \& Tiesdell, S. (2010). Assessing the publicness of public space: The star model of publicness. Journal of Urban Design, 15(4), 575-598.

Williams, K., \& Green, S. (2001). Literature review of public space and local environments for the cross cutting review. Prepared for Department of Transport, Local Government and Regions.

Zukin, S. (1998). Urban lifestyles: diversity and standardisation in spaces of consumption. Urban studies, $35(5 / 6), 825$. 